Ann. Biol. anim. Bioch. Biophys., 1979, 19 (4 B), 1179-1196.

\title{
The role of the mesonephros in the development of indifferent gonads and ovaries of the mouse
}

\author{
par S. UPADHYAY, J. M. LUCIANI*, L. ZAMBONI \\ Department of Pathology, Harbor-UCLA Medical Center, Torrance, California \\ 90509 and University of California School of Medicine, Los Angeles, USA. \\ * Département d'Histologie ef d'Embryologie, Université de Marseille, \\ Faculté de Médecine, Marseille, France.
}

Summary. The development of the sexually indifferent gonads and ovaries of the mouse was studied in embryos, fetuses, newborns and prepuberal animals from day 10 post-coitum through post-natal day 32.

The process of gonadal morphogenesis consists of three main phases. During colonization, the genital ridge area is seeded by primordial germinal cells and by epithelial cells contributed by the mesonephric tubules. At the end of sexual indifference, the newly differentiated ovary appears as a voluminous organ consisting of a solid mass of closely associated germinal and somatic (mesonephric) cells ; at its dorsal margin, numerous mesonephric tubules continue to contribute epithelial cells to the somatic cell population of the gonad.

During the phase of organization, the mass becomes invaded from its dorsal side by septa of connective tissue and by blood vessels, and cleaved into elongated formations of germinal and somatic (mesonephric) cells, the ovigerous cords. Due to the anatomical continuity of the ovarian cell mass and mesonephric tubules, and the direction of the invasive process, the ovigerous cords become the intraovarian prolongations of the mesonephric tubules developing gradually in a dorso-ventral, center-to-periphery direction. The development of the earliest follicles also occurrs during this phase : following early meiotic prophase, the germinal cells in the innermost (most dorsal) segments of the ovigerous cords enlarge, and the surrounding mesonephric cells become distributed coronally around them and become follicle cells. Adjacent follicles remain connected by narrow segments of cords not containing germinal cells.

During the phase of comparfmentalization, the mesonephric tubule-ovigerous cord continuum becomes subdivided into independent structures. This is due to maturation of the primitive stroma surrounding the various components of the continuum and its progressive transformation into a thick, fibrous connective tissue. The mesonephric tubules become separated from the ovigerous cords and condensed into an irregular epithelioid cell mass which remains confined at the hilus of the ovary. The ensuing compartmentalization of the various segments of the ovigerous cords results in the individualization of the follicles and the transformation of the somatic-cell-only portions of the cords into islets of interstitial (steroidogenic) cells.

The above findings demonstrate that the follicle and interstitial (steroidogenic) cells of the mouse ovary are of mesonephric origin. 


\section{Introduction.}

Even though the development of the mouse fetal ovary has been the subject of numerous studies, important aspects of the process remain to be elucidated. Especially unclear is the origin of the somatic cells which associate with the germinal cells in early stages of gonadal morphogenesis, contribute to the formation of the ovigerous cords and, at the time of follicle development, become follicle cells. For some authors, the precursors of the follicle cells derive from the coelomic mesothelium lining the surface of the ovary (Allen, 1904 ; Brambell, 1927 ; Everett, 1943) while, for others, they differentiate from the mesenchymal cells of the ovarian stroma (Peters and Pedersen, 1967). More recently, Byskov and Lintern-Moore (1973) reported that, in post-natal mouse ovaries, follicle formation takes place within the confines of a system of cellular tubules or cords originating from the region of the Wolffian duct, which they identified as the rete ovarii ; these authors concluded, therefore, that the precursors of the follicle cells are the epithelial cells of the rete. Considering that the rete ovarii is classically thought to derive from (Waldeyer, 1870 ; Janosik, 1885 ; von Kölliker, 1898 ; von Winiwarter, 1900 ; von Winiwarter and Sainmont, 1908), or to be connected with the mesonephros (Allen, 1904 ; Wilson, 1926 ; Gillman, 1948), the observations and the conclusions of Byskov and Lintern-Moore (1973) would appear to be largely in agreement with those of Zamboni ef al. (1979) who, studying the development of the sheep fetal ovary, demonstrated that the follicle cells are mesonephric in origin and that the mesonephros is one of the principal organizers of transitory and definitive ovarian structures, i. e., the ovigerous cords and the follicles.

It is evident that the development of the mouse ovary and the role played by the mesonephros in the morphogenesis of this organ needed to be studied further and more in detail. Moreover, what the rete ovarii exactly is and its precise relationship with the mesonephros also remained to be defined. With these objectives in mind, we decided to perform a detailed study of sexually indifferent gonads and ovaries of the mouse at sequential, close stages of development and maturation, from early embryonal to prepuberal age.

\section{Materials and methods.}

Sexually indifferent gonads and ovaries of 35 embryos, fetuses, newborn and prepuberal mice from day 10 post-coitum through post-natal day 32 were used for this study. Following fixation by intracardiac (Abrunhosa, 1972) or intravascular perfusion (Zamboni and Stefanini, 1968) with 2.5 p. 100 glutaraldehyde in $0.1 \mathrm{M}$ cacodylate buffer, the gonads and the ovaries were excised together with their surrounding retroperitoneal organs, i. e., the mesonephros or remnants thereof, the metanephros and the adrenal gland. The specimens were post-fixed in $1 \mathrm{p} .100 \mathrm{OsO}_{4}$ and then prepared for embedding in Epon 812 according to conventional procedures. Due to the complexity of the process to be investigated and the relative vastity of the organs involved, the tissue samples were studied primarily by high resolution light microscopy. The blocks were serially sectioned, some along a longitudinal and others along 
a transverse plane, at a thickness of approximately 1.0 micron; the sections were stained by flotation on warm Toluidine blue in water, and then studied and photographed with a Zeiss Ultraphot or Photomicroscope. Whenever required, the blocks were sectioned also for electron microscopy; the thin sections were stained with lead hydroxide and examined with a Hitachi HU11E microscope.

\section{Observations.}

For a clearer comprehension of the observations made in the course of our study, the description of the process of ovarian development will be preceded by a concise survey of the structural organization of the mouse mesonephros as seen in the youngest embryos of our series prior to the appearance of the genital ridge (10 days of fetal life).

The mesonephros of the mouse has a simpler and more primitive organization than mesonephroi of other mammals (Leeson, 1960 ; De Martino and Zamboni, 1966). It lacks identifiable glomeruli and consists exclusively of tubules orderly aligned in a cranio-caudal direction (fig. 1). While dorsally the tubules drain into the Wolffian duct, ventrally they terminate only a few microns from the coelomic mesothelium lining the ventral surface of the organ (fig. 1). The tubules are demarcated by a continuous basal lamina and have an organization suggesting very limited excretory functions, if any. Lumina are present but the apical portions of the epithelial cells are provided only with a few rudimentary microvilli ; cytoplasmic elements associated with reabsorption (apical microvesicles, protein reabsorption droplets, etc.) are few or non-existent.

In the description to follow, the development of the mouse ovary will be subdivided into three phases : colonization, organization and compartmentalization. If is obvious that this subdivision is entirely arbitrary and made exclusively for the sake of clarity since the process was seen to evolve gradually without any demarcation between stages.

\section{The phase of colonization.}

At day 10 of fetal life, the region between the ventral terminations of the mesonephric tubules and the coelomic mesothelium, i.e., the site where the gonad is to develop appeared as a narrow strip of mesenchyme containing exclusively a scattering of primitive mesenchymal cells and thin-walled vascular lacunae (fig. 1).

Onset of gonadal morphogenesis was first seen at day 11 of fetal life, and was heralded by the arrival in this region of the first few primordial germinal cells ; germinal cell colonization of the area occurred as reported in previous studies (Jeon and Kennedy, 1973 ; Zamboni and Merchant, 1973) and, therefore, will not be described again here. Simultaneously with the arrival of the germinal cells, somatic cells of mesonephric origin, the precursors of the definitive follicle cells, also invaded the region. They egressed from the ventral terminations of the mesonephric tubules (figs 2, 3, and 4) which, in these regions, were now characterized by highly irregular profiles (figs 2, 3, and 4), and by discontinuities or absence of their basal laminae 
(fig. 4) ; the cells simply separated from neighboring cells, detached from the walls of the tubules and entered into the adjacent mesenchyme (figs 2, 3, and 4). Here, they appeared to be preferentially associated with the germinal cells which they surrounded with most of their surfaces, the plasma membranes of the two cells being intimately apposed against one another in a parallel fashion. A characteristic of the mesonephric cells which were about to be, or were in the process of being mobilized from the walls of the tubules was the presence in the cytoplasm of numerous pleomorphic lysosome-like bodies (fig. 2), probably required for the enzymatic digestion of the basal lamina ; an intense mitotic activity also characterized the mesonephric cells in and outside the tubules (figs 2 and 3). Germinal and mesonephric cell colonization of the genital ridge appeared to occur at the expense of the mesenchymal cells originally present in the area ; they were displaced by the colonizing cells and decreased rapidly and considerably in number shortly after the onset of gonadal development.

By day 12 of fetal life, the originally narrow, flat and sparsely populated genital ridge had developed into a rather voluminous organ, the sexually indifferent gonad, protruding into the coelomic cavity with a slightly curved ventral surface (fig. 5). The organ was entirely occupied by a compact mass of somatic cells of mesonephric origin and germinal cells (figs 5 and 6), tightly apposed against one another and separated only by extremely narrow, slit-like spaces (fig. 6) ; the mass did not include any stromal or interstitial components (figs 5 and 6), except rare capillary vessels (fig. 5). The somatic cells of mesonephric origin, which at this stage outnumbered the germinal cells, exhibited epithelioid characters and had large, slighily indented nuclei with finely dispersed chromatin (fig. 6). Their cytoplasm was expanded and crowded predominantly by a multitude of small, rod-shaped, dense mitochondria (fig. 6).

At the dorsal margin of the gonad, numerous mesonephric tubules continued to contribute cells to the organ (fig. 5); due to the fact that the ventral ends of the fubules now abutted directly against the dorsal aspect of the gonadal cell mass, the mesonephric cells became incorporated into it as soon as they egressed from the

FIG. 1. - Ten-day-old embryo.The mesonephric tubules are regularly aligned in a cranio-caudal orientation with their ventral extremities situated just below the mesothelial cell layer lining the coelomic cavity (CC). At this early stage of development, the genital ridge area consists exclusively of a primitive mesenchyme and thin-walled vascular lacunae. Tolvidine blue stained section $\times 130$.

FIG. 2. - Eleven-day-old embryo. The colonization of the genital ridge area by the epithelial cells of the mesonephric tubules has begun. The cells separate from the walls of the tubules and enter the narrow region comprised between the ventral extremities of the tubules and the surface mesothelial cell layer. Notice the irregular margins of the tubules on their ventral side and the presence of prominent lysosome-like bodies in the epithelial cells egressing from the tubules. Toluidine blue stained section $\times 400$.

FIG. 3. - Eleven-day-old embryo. Another aspect of mesonephric cell colonization of the genital ridge. An intense mitotic activity characterizes the fubular epithelial cells (see also fig. 2). Toluidine blue stained section $\times 400$.

FIG. 4. - Eleven-day-old embryo. Electron micrograph illustrating in detail the process of separation of the epithelial cells from the ventral aspect of the wall of a mesonephric tubule and their release into the genital ridge. Notice the absence of a basal lamina around the ventral margin of the tubule. TL, tubule lumen $\times 2,250$. 


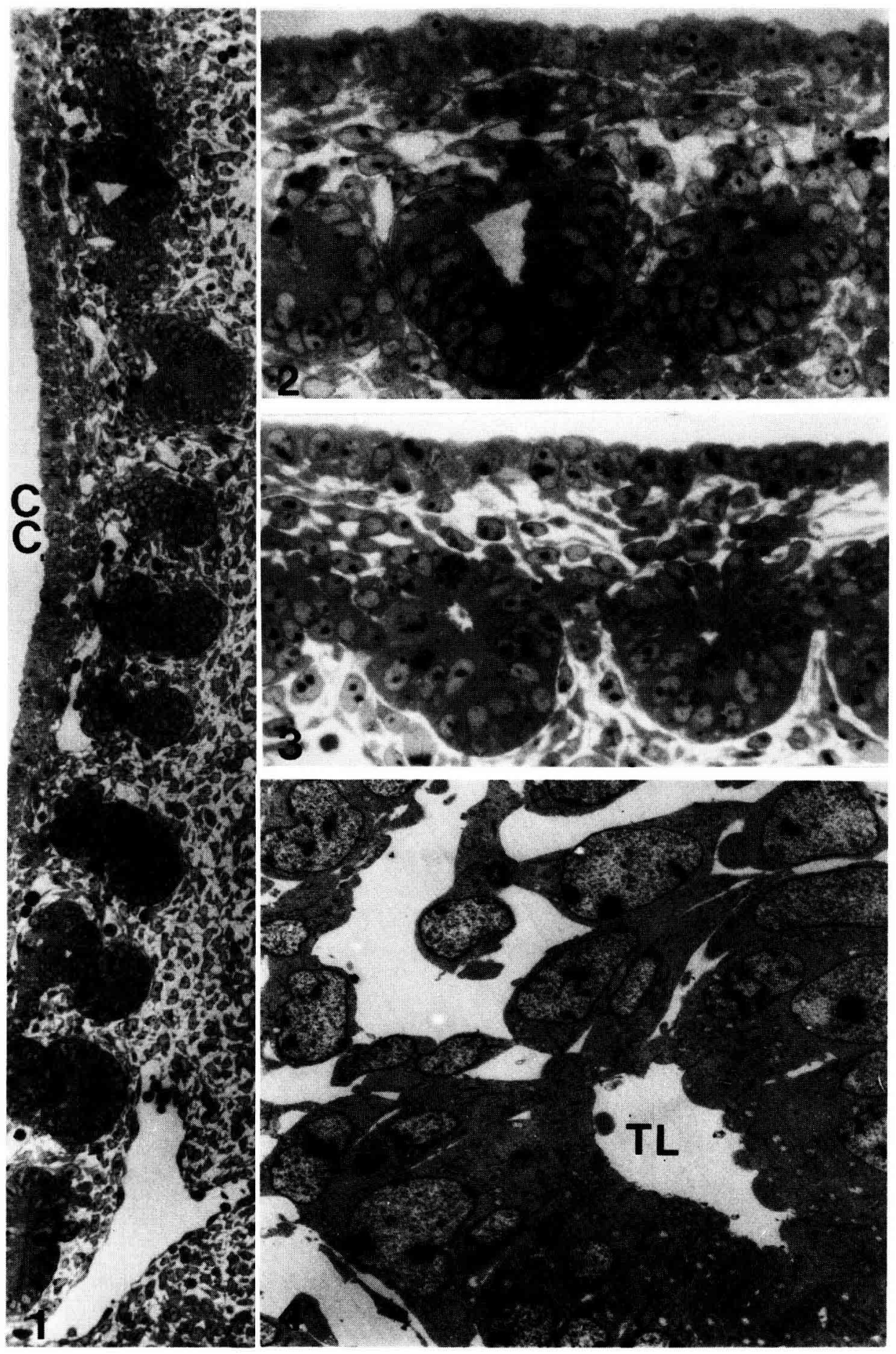


walls of the tubules (figs 5 and 7). The very close topographic relationship between the terminations of the tubules and the gonadal cell mass made it often difficult to establish the boundaries between the fwo structures by light microscopy (fig. 5).

Simultaneously with progressive gonadal development, the mesonephric tubules assumed characteristics of a higher degree of organization, and became narrower and more elongated (compare figs 2 and 3 with figs 5, and fig. 4 with fig. 7). At day 12 of fetal life, their terminal segments, i.e., those situated just dorsal to the gonadal cell mass also began to display features different from those of the more dorsal segments. They had slit-like lumina (fig. 7), and their walls were lined by cells similar in several respects to the mesonephric cells in the gonad; for example, they showed a somewhat decreased affinity for the Toluidine blue (arrows, fig. 5), and modifications in the configuration of the milochondria, which changed abruptly from large and spheroidal to small and rod-shaped like those of the mesonephric cells in the gonadal cell mass (fig. 7). The similarities between the mesonephric cells in the terminal segments of the tubules and those in the gonads further contributed to the difficulty of establishing the actual boundary between the tubules and the gonads by light microscopy. The limits between the two structures could be traced accurately only by electron microscopy, and were identified as the regions where the mesonephric tubules lost their basal laminae (fig. 7).

Sexual differentiation of the gonad was clearly detected at day $131 / 2$ of fetal life. The newly differentiated ovary (fig. 8) appeared as a voluminous organ protruding considerably into the coelomic cavity and consisting of a highly compact mass of somatic cells of mesonephric origin and germinal cells. Numerous mesonephric tubules, anatomically continuous with the cells of the mass, continued to be present at the dorsal margin of the ovary (fig. 8).

\section{The phase of organization.}

At approximately day 16 of fefal life, the ovarian cell mass began to become invaded by septa of connective tissue and by medium size blood vessels entering from the dorsal margin of the ovary and advancing alongside the walls of the mesonephric tubules in a dorso-ventral direction (figs 9 and 10). These elements progressively cleaved the solid cellular mass into elongated formations of germinal and mesonephric (prefollicle) cells, the ovigerous cords (figs 9, 10 and 11). Due to the intimate relationship

FIG. 5. - Twelve-day-old embryo. The sexually indifferent gonad consists of a highly compact mass of germinal and somatic (mesonephric) cells protruding slightly into the colomic cavity with its ventral surface. The gonad is lined by a single layer of mesothelial cells well demarcated from the underlying cell mass. Notice that the mass does not seem to include mesenchymal elements and is pervaded only by a few blood capillaries. At its dorsal margin, epithelial cells continue to be added to the gonad from the ventral extremities of the mesonephric tubules. Notice the decreased affinity for Toluidine blue of the cells in the most ventral portions of the fubules (arrows) which renders these cells tinctorially similar to those in the mass. Toluidine blue stained section $\times 320$.

FIG. 6. - Twelve-day-old embryo. Electron micrograph of a portion of the gonadal cell mass to show the close apposition of germinal $(G)$ and somatic (mesonephric) cells. Notice the dense, rodshaped mitochondria in the cytoplasm of the somatic cells $\times 3,000$. 


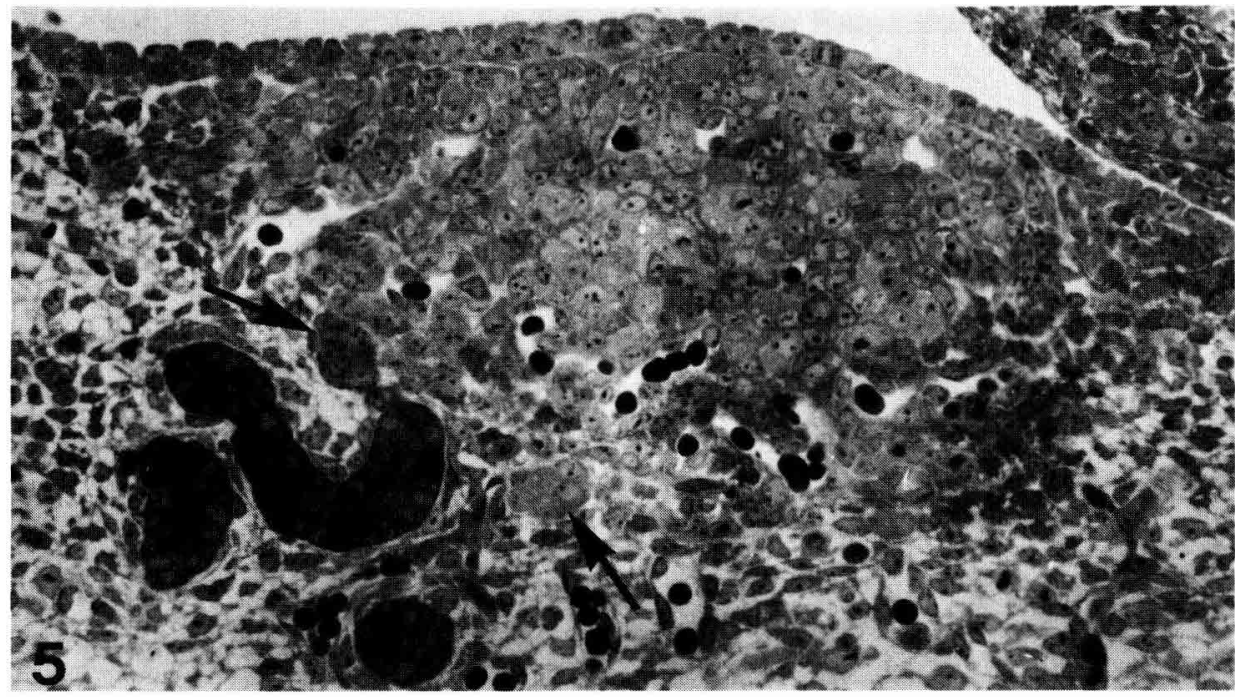

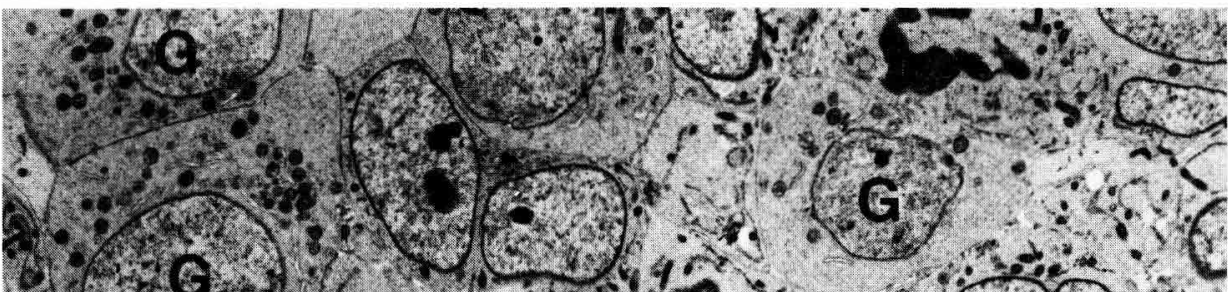

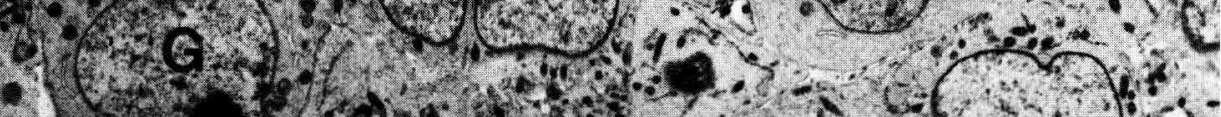

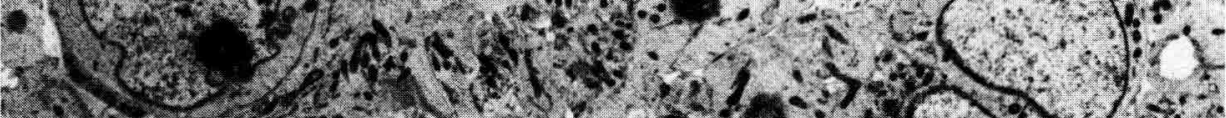

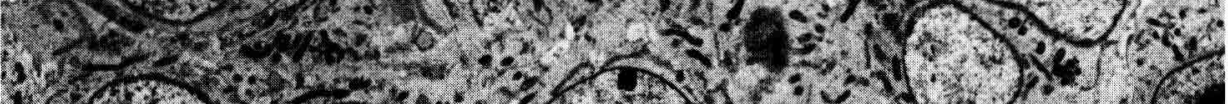

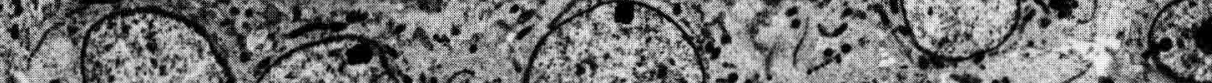

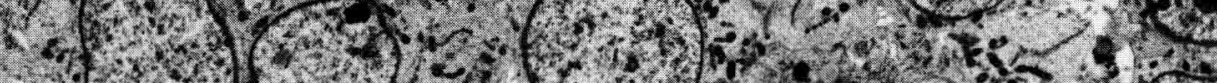

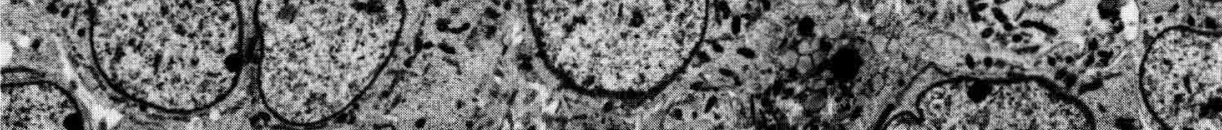

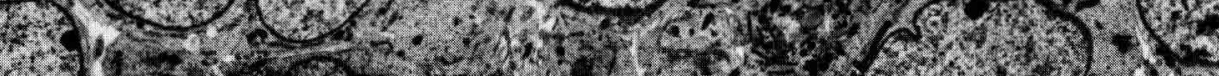

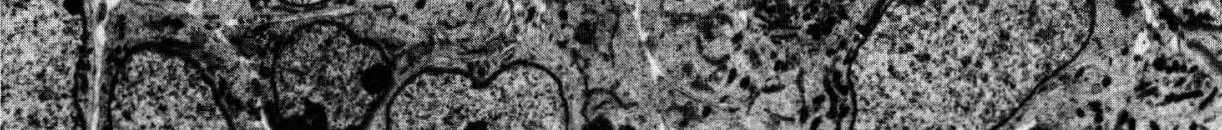

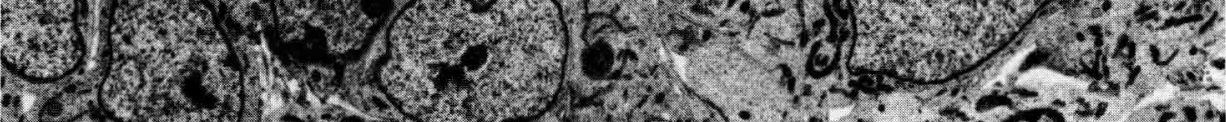

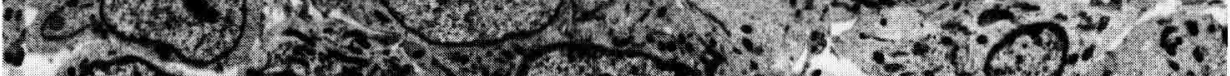

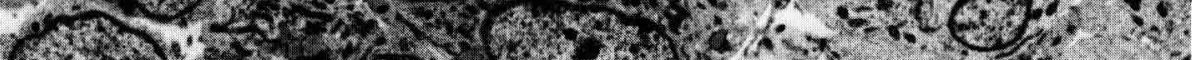

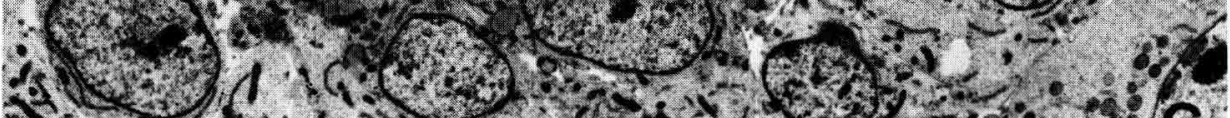

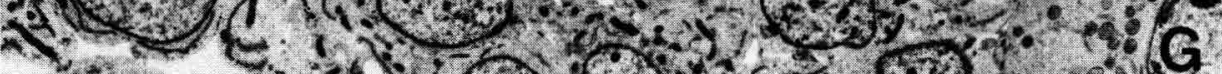

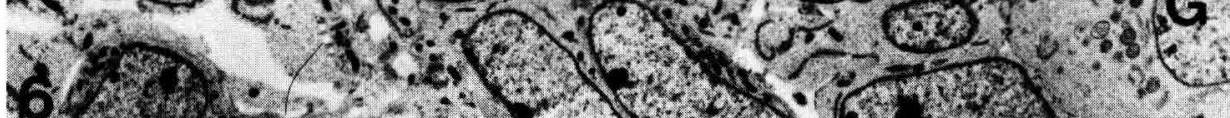
o. 
which existed already between the ovarian cell mass and the mesonephric tubules, and the direction of the invasive process, the developing ovigerous cords appeared as extensions or prolongations of the mesonephric tubules within the ovarian territory (figs 10 and 12). Since the ovigerous cords developed gradually and in a dorso-ventral direction, at any given time their most dorsal segments were more highly organized than the ventral portions; an example of this gradient of organization was the development of the basal laminae which formed around the cords gradually and as extensions of the basal laminae of the mesonephric tubules (figs 10 and 12). In incipient stages of the cleaving process, the cords were thick and had rather straight, radial courses (figs 9 and 10); by the time the connective tissue and the blood vessels reached the periphery of the ovary (day 19 of fetal life), the ovigerous cords had increased considerably in length and extended with sinuous courses from the mesonephric tubules at the dorsal margin of the ovary to the surface of the gonad where their cells and basal laminae established contact, and became anatomically continuous, with the corresponding elements of the surface mesothelium (fig. 13). At this stage, thus, a continuum of structures extended from the Wolffian duct to the ovarian surface.

Meiotic oocytes (figs 9, 11 and 12) were first seen at day 16 of fetal life and the first follicles appeared at day 19 (end of gestation) and post-natal day 1 (figs 13 and 14). The process of follicle formation initiated in the innermost (dorsal) region of the ovary (fig. 13) from where it subsequently spread as a wave towards the periphery. Follicle formation occurmed within the confines of the ovigerous cords; the oocytes enlarged conspicuously, the segments of the cords where they were contained expanded, and the prefollicle (now follicle) cells became arranged coronally around the oocytes (fig. 14). The newly formed follicles remained connected to one another by portions of cords which had not undergone expansion as they did not contain germinal cells ; these non-dilated segments represented the structures that in a previous report from our laboratory were referred to as interfollicular connections (Merchant and Zamboni, 1972). The alternation of dilated and non-dilated segments imparted to the ovigerous cords a rosary-like appearance where the beads were represented by the follicles linked together by the non-dilated portions of the cords (fig. 14).

The development of the earliest follicles was soon followed by the degeneration of their oocytes ; the follicle cells were not affected by the regressive process, however, and, in fact, they were often seen to be involved in the disposal of remnants of the degenerated oocytes by phagocytosis. Oocyte degeneration also spread gradually and in a dorso-ventral direction. Thus, since the time the first oocytes underwent regression, two main regions could be distinguished in the ovary, a central one characterized by cords depleted of germinal elements and consisting only of somatic cells, and a peripheral one with portions of cords where the germinal cells were

FIG. 7. - Twelve-day-old embryo. Montage of mesonephric tubule contributing epithelial cells to the sexually indifferent gonad. The center micrograph covers the area where the tubular basal lamina disappears and cell liberation occurs. Note the abrupt transformation of the mitochondria in the cells near the site of release from the tubules which change from spheroidal and plump (lower right corner) to rod-shaped, thin and dense like those of the somatic (mesonephric) cells in the gonadal mass $(G M) \times 1,500$. 


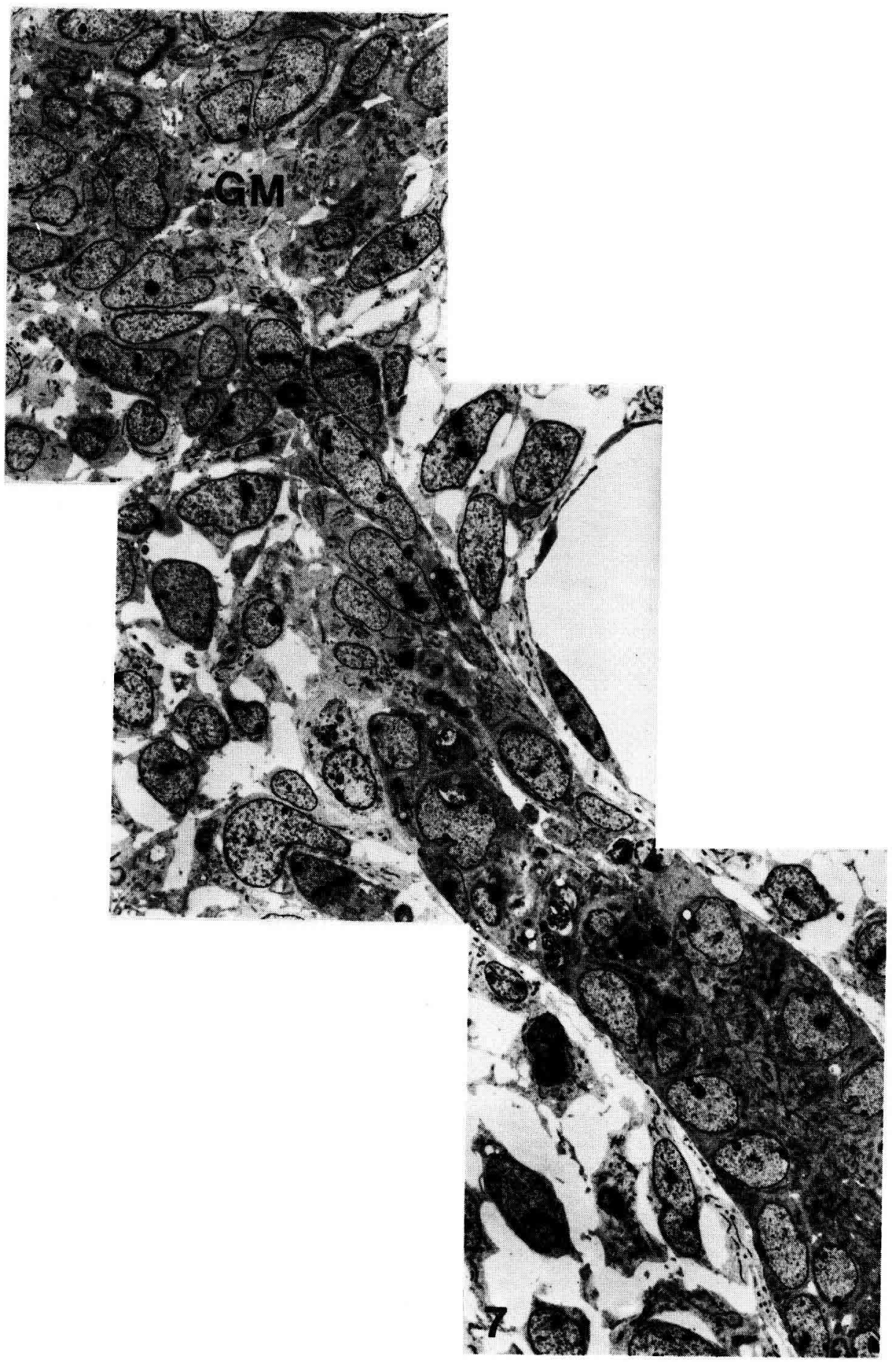


abundantly represented ; the two regions were separated by a zone of ollicle development (fig. 15). The extension of each region and the localization of the transitional zone of follicle formation between them, varied in sequential stages of development. With increasing age, and as result of the spreading of oocyte degeneration towards the periphery of the ovary, the region of somatic-cell-only cords (the rudiment of the medulla) expanded at the expense of the outermost area (the rudiment of the cortex), and the zone of developing follicles shifted progressively towards the periphery.

\section{The phase of compartmentalization.}

Beginning with post-natal day 7 , the structural continuum extending from the Wolffian duct to the surface of the ovary became compartmentalized into independent sections ; these changes appeared to result from the maturation of the primitive stroma around the mesonephric tubules and in the ovary, and its transformation into a thick, fully differentiated connective tissue characterized by large numbers of fibroblasts in a dense, collagen-rich ground substance (fig. 16). A lso, these changes occurred gradually and along an outwardly direction; thus, the compartmentalization affected the mesonephric tubules at first and the ovarian structures later, those closest to the surface of the ovary being affected the last.

Due to encroachment of the surrounding dense connective tissue, the mesonephric tubules became separated from the Wolffian duct at one extremity and from the ovigerous cords, at the other. They decreased considerably in extension, condensed into a deeply infolded epithelioid mass and remained confined within the hilar region of the ovary (fig. 16) ; the cells lost their orderly alignment along the walls, and an irregular, crenated lumen was occasionally seen in the center of the transformed structure. The characteristics of this formation appeared similar to those of the rete ovarii as described in adult ovaries of several species (Mossman and Duke, 1973).

Compartmentalization of the various segments of the ovigerous cords ensued. The somatic-cell-only and the interfollicular segments of the cords were pinched off and separated from the follicles which, thus, became individualized ${ }^{(1)}$. The com-

(1) The cells in these isolated remnants of the ovigerous cords subsequently underwent differentiation into interstitial (steroidogenic) cells ; this subject will be considered in detail in another report.

FIG. 8. - Fourteen-day-old fetus. The newly differentiated ovary consists of a solid mass of germinal and somatic cells which continue to be contributed to the ovary by the mesonephric tubules at the dorsal margin (arrows). The Wolffian duct is visible in the lower part of the micrograph. Toluidine blue stained section $\times 110$.

FIGS 9, 10 and 11. - Sixteen-doy-old (figs 9 and 10) and 17-day-old (fig. 11) fetuses. Various aspects of the invasion of the ovarian cell mass by connective tissue and vessels advancing into the ovary from its dorsal aspect and along the walls of the mesonephric tubules. The cleaving of the mass into elongated ovigerous cords of germinal and prefollicle cells is evident. Meiotic oocytes can be distinguished in figs 9 and 11 . Tolvidine blue stained sections: figs 9 and $10 \times 220$; fig. $11 \times 400$.

FIG. 12. - Eighteen-day-old fetus. The continuity between a mesonephric tubule (MT) and ovigerous cords with meiotic oocytes is clearly shown in this micrograph (see also figs 9 and 10). Tolvidine blue stained section $\times 400$. 


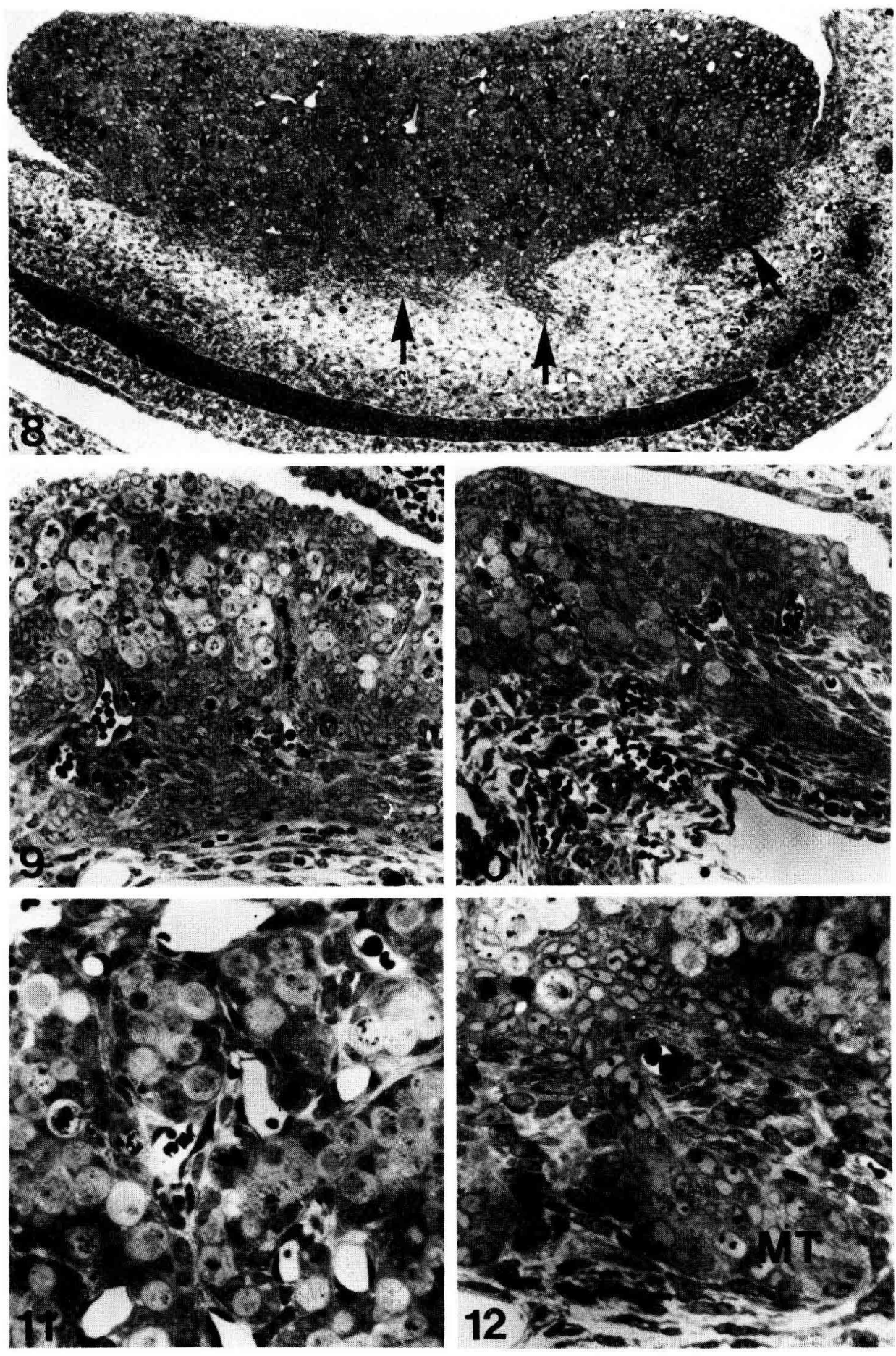


partmentalization process culminated with the development of a thin layer of mature connective tissue at the extreme periphery of the ovary, the funica albuginea, and the separation of the outermost layers of follicles from the cells lining the surface of the ovary.

\section{Discussion.}

The results of this study demonstrate that, in the mouse, the mesonephros is the source of the somatic cells which establish early and permanent association with the germinal cells, contribute to the formation of the ovigerous cords and, eventually, differentiate into follicle and ovarian interstitial cells; as such, the mesonephros directly participates to the development of indifferent gonads and ovaries. In fact, this could very well be the main, if not exclusive, role of the mouse mesonephros since, due to its rudimentary organization and the lack of identifiable glomeruli, the organ appears hardly capable of performing any excretory function. The observation that the mesonephros of the mouse does not undergo involution as it does in other species (Altschule, 1930 ; Gersh, 1937 ; Willis, 1958 ; Bernier and Beaumont, 1964 ; Langman, 1967 ; De Martino et al., 1977) but, to a certain degree, increases in extension and organization concomitantly with progressive gonadal development, is a further indication of the close functional relationship binding the two organs.

The observations and conclusions of this study confirm and extend those made previously by Byskov and Lintern-Moore (1973) who demonstrated that, in the mouse, follicle formation occurs within the confines of a network of cords of epithelial cells which these authors referred to as rete ovarii, identified as mesonephric in origin and

FIG. 13. - Ninefeen-day-old fetus. Ovigerous cord development has reached the periphery of the ovary (arrows). In the central region of the gonad (center right of the micrograph), the cords are tortuous and focally expanded due to development of the early follicles. Toluidine blue stained section $\times 220$.

FIG. 14. - One-day-old mouse. Follicle development within the confines of the innermost portions of the cords. Notice the narrow segments of cords linking adjacent follicles. Tolvidine blue stained section $\times 400$.

FIG. 15. - Four-day-old mouse. The incipient subdivision of the ovary in different areas with different characteristics and structural elements is evident in this micrograph. The central region is occupied prevalenfly by somatic-cell-only portions of the ovigerous cords (for explanation, see text). This region, which is the rudiment of the medulla, contrasts with the peripheral zone (the rudiment of the cortex) occupied by cords with an abundance of germinal cells and small follicles. Between the two regions there is a transitional zone of follicle development. The anatomical continuity befween all these structures, from the mesonephric tubules (MT) to those near the surface of the ovary, is evident. Toluidine blue stained section $\times 160$.

FIG. 16. - Seven-day-old mouse. As result of the ongoing compartmentalization process (for explanation, see text), mesonephric tubules and follicles have become individualized. The various elements are surrounded by conspicuous amounts of thick, mature connective fissue. Notice the incipient transformation of the mesonephric tubules into a condensed, irregular epithelioid mass at the hilus of the ovary. Tolvidine blue stained section $\times 150$. 

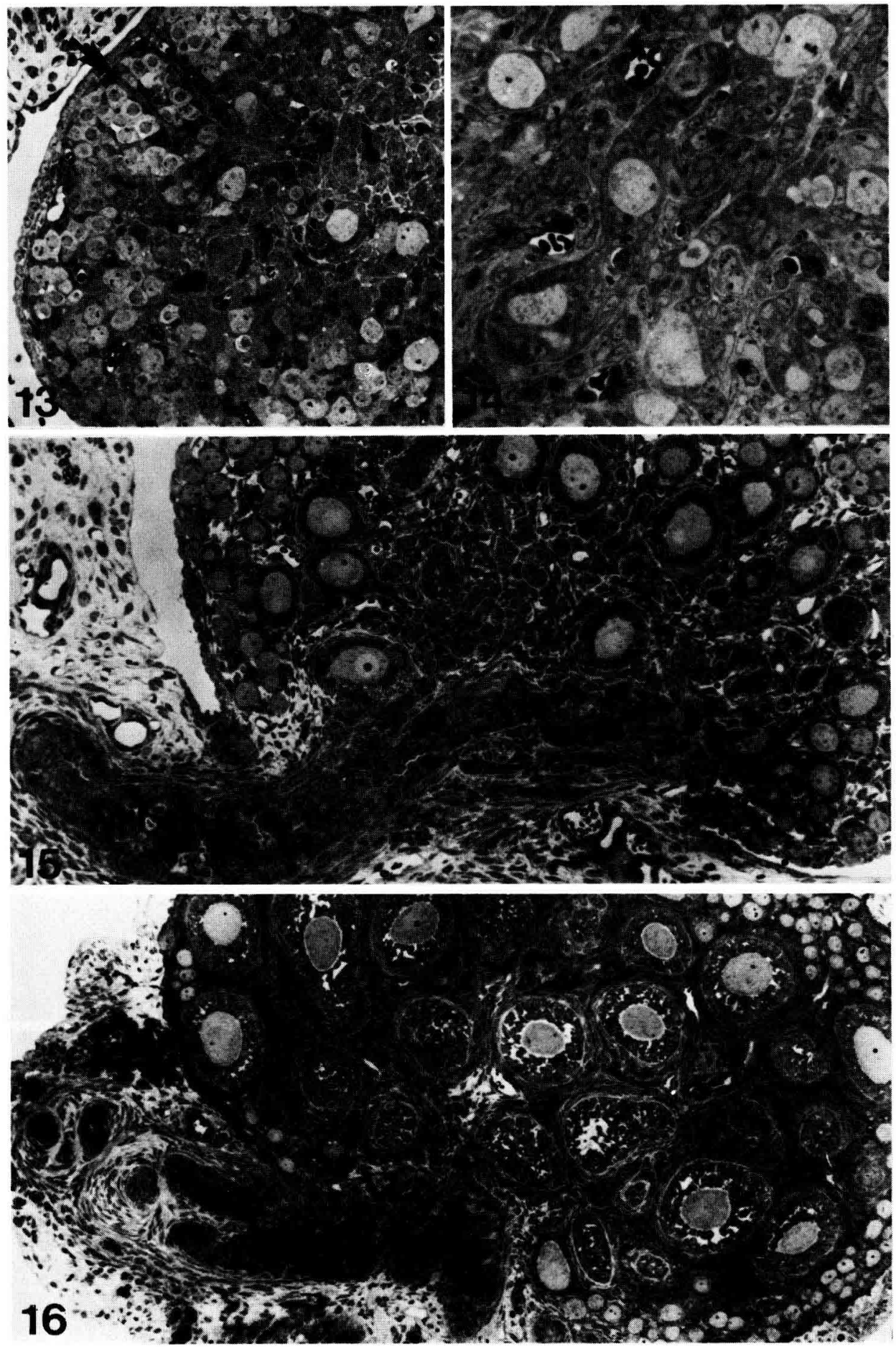
subdivided into an extraovarian, intraovarian and connecting rete; in complete agreement with our findings, these authors concluded that the precursors of the follicle cells are prevalently of a mesonephric origin. Our study, which includes developmental stages much earlier than those considered by Byskov and Lintern-Moore (1973), reveals additionally that the structures which these authors referred to as rete ovarii are the mesonephric tubules and their intraovarian ramifications, the ovigerous cords. What Byskov and Lintern-Moore (1973) called the extraovarian rete are the mesonephric tubules, the connecting rete, the most ventral portions of the fubules from where epithelial cells are released into the ovary, and the intraovarian rete, the ovigerous cords which form at the time the solid ovarian mass of mesonephric and germinal cells becomes cleaved by septa of connective tissue and blood vessels. That this is indeed the case was confirmed recently by Byskov (1978) who, studying the refe system in 12 1/2-day-old mouse fetuses, recognized that the structures that she previously referred to as extraovarian rete are the mesonephric tubules.

Our results also reconcile with those of another study by Zamboni et al. (1979), demonstrating the important role played by the mesonephros in the development of the sheep ovary. With the only exception of the actual site of origin of the mesonephric cells (in the sheep, the giant mesonephric nephron and, in the mouse, the mesonephric tubules), in both species all fundamental aspects of the process are analogous. In both cases :

- the process involves prevalently mesonephric cells egressing from the confines of their structures of origin, and colonizing the gonadal territory ;

- the process of mesonephric cell colonization of the gonad initiates well before sexual differentiation ;

- mesonephric cell colonization of the gonads occurs simultaneously with, and spans the same length of time as, the arrival of the germinal cells in the gonadal region ; and

- the migration, colonization and organization processes follow a front advancing from the mesonephros towards and into the gonad.

The observation that sheep and mouse gonads begin to undergo colonization by the mesonephric cells prior to their sexual differentiation, indicates that no differences exist between genetic sexes insofar as mesonephric behavior and the role of this organ in gonadal development are concerned. This has been confirmed by studies performed in our laboratory which have shown that in both species, also the Sertoli cells are of mesonephric origin (unpublished).

The existence of a system of cellular tubules or cords extending between the mesonephros and the developing ovary is not a new observation as it had been reported already by classic investigators (Waldeyer, 1870 ; Janosik, 1885 ; Kölliker, 1898 ; Winiwarter, 1900 ; Allen, 1904 ; Winiwarter and Sainmont, 1908 ; Wilson, 1926 ; Gillman, 1948). These authors claimed, however, that the system forms as result of the establishment of connections between the two organs, as consequence of either the growth of the ovigerous cords outside the ovary towards the mesonephros, or the proliferation of epithelial cell cords from the mesonephros into the ovary where they would become continuous with the tips of the ovigerous cords streaming down from 
the surface of the organ. It is evident from the results of our study that the structures which extend from the Wolffian duct to the surface of the ovary do not consist of elements having different origins and becoming connected at given stages of development ; they constifute instead a single, continuous system which begins to form at the time the first epithelial cells of the mesonephric tubules are contributed to the developing genital ridges, and which, in subsequent stages, continues to develop progressively as result of a front of organization advancing from the mesonephros towards and into the gonad. In such a system, the ovigerous cords do not establish contact with the mesonephric tubules as previous investigators maintained and as the misnomer " connecting rete " (Byskov and Lintern-Moore, 1973) suggests, but they are the intraovarian prolongations of the tubules themselves.

No evidence was obtained in our study of any contribution by the mesothelial cells lining the surface of the indifferent gonad or the ovary to the structures developing in subjacent areas. At the genital ridge stage (days 101/2-11 of fetal life), the mesothelial cells appeared to be clearly separated, and could be easily distinguished from the mesonephric and germinal cells colonizing the area. In subsequent stages of development, they appeared always sharply demarcated from the underlying solid mass of mesonephric and germinal cells. It was only when the process of ovigerous cord formation reached the surface of the ovary that contact between the mesothelial cells and the most superficial segments of the cords was established, together with focal anatomical continuities between the basal laminae of the two structures. Furthermore, the dorso-ventral, center-to-periphery direction of gonadal development and organization demonstrated in our study hardly allows for any participation of the surface mesothelial cells to the morphogenesis of subjacent structures. The mitotic activity of the surface mesothelial cells, so frequently advocated to support their alleged proliferation into the underlying stroma, and noted also in the present study, simply can be accounted for by the necessity that these cells increase in number to provide a continuous lining to the growing organ. Similarly, no evidence was obtained in this study in support of the hypothesis that the follicle cells originate from the gonadal mesenchyme ; our observations instead show that, at least in early stages of development, the massive colonization of the gonadal territory by the germinal and mesonephric cells induced displacement of the original mesenchymal elements.

The observations made in the course of our study contribute to clarify also other confusing views which, in our opinion, mostly derive from inadequate monitoring of the highly complex process of ovarian development. One of these concerns the existence of a " blastema », described by several authors as a solid mass of prevalently somatic cells in the center of developing gonads of different species, to which different origins, roles and fates were attributed. Witschi $(1951,1956,1962)$, who identified the blastema as the " primitive medulla 》 of the gonad, maintained that it consisted of cells of mesonephric origin and that it disappeared early during development. Gropp and Ohno (1966), in the cow, referred to it as medullary blastema, could not determine its origin, and postulated that it gives rise to all somatic cells of the male and female gonads (Sertoli and Leydig cells, and follicle and interstitial cells). For Merchant (1975), the origin of the blastema is multiple since, according to this author, it deri- 
ves from all cell types present in and around the gonad, i. e., surface mesothelial, mesenchymal and mesonephric cells. Our findings, and those of Zamboni et al. in the sheep (1979), now show that this blastema simply represents a phase of aggregation of the mesonephric and germinal cells which colonize the ovarian territory; in the mouse, this phase lasts from day 12 of fetal life, when the mesonephric and germinal cells in the gonad attain considerable numbers and become compactly arranged, to day 16 when the solid mass of mesonephric and germinal cells begins to be cleaved into ovigerous cords.

Another confusing view concerns the alleged occurrence of at least two categories of cords, medullary and cortical ; for many authors (Allen, 1904 ; Brambell, 1927 ; Everett, 1943 ; Gillman, 1948), these cords all originate from the surface mesothelium but in different stages of development, the medullary cords forming prior to sexual differentiation of the gonad, and the cortical after sexual differentiation and exclusively in the ovary. According to Witschi (1951, 1956, 1962), instead, the medullary cords form from a primitive blastema of mesonephric origin (see above), while the cortical cords originate from the surface epithelium. All authors agree, however, that the medullary cords, as well as the follicles which develop from them in relatively early stages of ovarian morphogenesis, regress and disappear, and that definitive follicles originate only from the cortical cords. Our observations now show that only one type of cord exists, the ovigerous cords, the so-called medullary cords being but their innermost segments, and the cortical, their outermost. The erroneous impression of the occurrence of different types of cords forming in different stages of development and undergoing regression in a selective fashion most probably stems from the fact that the ovigerous cords develop gradually in sequential morphogenetic stages and along a dorso-ventral center-to-periphery direction, and that their innermost segments, together with the early follicles which form from them, become gradually depleted of germ cells.

4th Workshop on " Development and maturation of the reproductive organs and functions " Luynes, France, octobre 1978.

Acknowledgments. - This study was supported by a USPHS research grant (\# HD09913-02) to L. Zamboni and DGRST research grant from the French Government to J. M. Luciani.

Résumé. Le développement de gonades sexuellement indifférenciées et d'ovaires de souris a été étudié chez des embryons, des fœtus et des animaux nouveau-nés et prépubères de 10 jours post coïtum à 32 jours après la naissance.

L'évolution de la morphogenèse de la gonade comporte trois phases principales. Pendant la colonisation, la région de la crête génitale est envahie par des cellules germinales primordiales et par des cellules épithéliales fournies par les tubules mésonéphriens. A la fin de la période d'indifférenciation sexuelle, l'ovaire nouvellement différencié apparaît comme un organe volumineux constitué d'une masse compacte de cellules germinales et somatiques (mésonéphriennes) étroitement associées; sur le bord dorsal de nombreux tubules mésonéphriens continuent à fournir les cellules épithéliales à la population des cellules somatiques de la gonade.

Durant la phase d'organisation, la masse est envahie dans sa partie dorsale par des septa de tissu conjonctif ef par des vaisseaux sanguins et se divise en formations allongées 
de cellules germinales et somatiques (mésonéphriennes), les cordons ovigères. En raison de la continuité anatomique de la masse de cellules ovariennes et des tubules mésonéphriens ainsi que de la direction du processus d'invasion, les cordons ovigères deviennent les prolongements intraovariens des tubules mésonéphriens se développant progressivement dans une direction dorso-centrale et du centre vers la périphérie. Le développement des premiers follicules survient aussi pendant cette phase : après avoir franchi les stades précoces de la prophase méiotique, les cellules germinales des segments les plus internes (les plus dorsaux) des cordons ovigères grossissent et les cellules mésonéphriennes les entourant se distribuent en couronne autour des cellules germinales ef deviennent des cellules folliculeuses. Les follicules adjacents demeurent en relation par d'étroits segments de cordons ne contenant pas de cellules germinales.

Durant la phase de formation de compartiments, le continuum cordons ovigères tubules mésonéphriens se subdivise en structures indépendantes. Ceci est dû à la maturation du stroma primitif entourant les divers composants du continuum et à sa transformation progressive en un tissu conjonctif épais et fibreux. Les fubules mésonéphriens se séparent des cordons ovigères et se condensent en une masse irrégulière de cellules épithélioïdes qui restent confinées au niveau du hile de l'ovaire. La fragmentation des divers segments des cordons ovigères consiste en la formation de follicules individualisés et en la transformation des parties ne contenant que des cellules somatiques en îlots de cellules inferstitielles (stéroïdogènes).

Les résultats ci-dessus démontrent que le follicule ef les cellules interstitielles (stéroïdogènes) de l'ovaire de souris sont d'origine mésonéphrienne.

\section{References}

ABRUNHOSA R., 1972. Microperfusion fixation of embryos for ultrastructural studies. J. Ultrastruct. Res., 41, 176-188.

ALLEN B. M., 1904. The embryonic development of the ovary and festis of the mammals. Am. J. Anat., 3, 89-146.

ALTSCHULE M. D., 1930. The changes in the mesonephric tubules of human embryos ten to twelve weeks old. Anat. Rec., 46, 81-91.

BERNIER N., BEAUMONT A., 1964. Structure ef régression du mésonéphros du foetus du lapin. C. R. Soc. Biol., 158, 2227-2230.

BRAMBELL F. W. R., 1927. The development and morphology of the gonads of the mouse. Part 1, The morphogenesis of the indifferent gonad and the ovary. Proc. roy. Soc. London, Ser. B., 101, $391-409$.

BYSKOV A. G., 1978. The anatomy and ultrastructure of the rete system in the fetal mouse ovary. Biol. Reprod., 19, 720-735.

BYSKOV A. G., LINTERN-MOORE S. M., 1973. Follicle formation in the immature mouse ovary. The role of rete ovarii. J. Anat., 116, 207-217.

DE MARTINO C., ZAMBONI L., 1966. A morphologic study of the mesonephros of the human embryo. J. Ulirasiruct. Res., 16, 339-427.

DE MARTINO C., ZAMBONI L., ACCINNI L., 1977. Fine morphology of regressing human mesonephric nephrons. Exp. mol. Pathol., 26, 169-183.

EVERETT N. B., 1943. Observational and experimental evidences relating to the origin and differentiation of the definitive germ cells in mice. J. exp. Zool., 92, 49-91.

GERSH J., 1937. The correlation of structure and function in the developing mesonephros and metanephros. Contrib. Embryol., Carnegie Inst., 26, 33-58.

GILLMAN J., 1948. The development of the gonads in man, with a consideration of the role of fetal endocrines and the histogenesis of ovarian fumors. Contrib. Embryol. Carnegie Inst., 32, 82 131.

GROPP A., OHNO S., 1966. The presence of a common embryonic blastema for ovarian and testicular parenchymal (follicular, interstitial and tubular) cells in the cattle, Bos taurus. Z. Zellforsch, 74, 505-528. 
JANOSIK J., 1885. Histologische-embryologische Untersuchungen über das Urogenitalsystem. Sitzunsberg. Kais. Akad. Wissensch. Wien, 91, 97-199.

JEON K. W., KENNEDY J. R., 1973. The primordial germ cells in early mouse embryos ; light and electron microscopic studies. Develop. Biol., 31, 275-284.

KÖLLIKER von A., 1898. Über die Markkanäle und Markstränge in den Eierstöcken junger Hundinnen. Verhandl. Anat. Gesellsch. Jena.

LANGMAN J., 1967. Medical Embryology. Williams and Wilkins, Baltimore.

LEESON T. S., 1960. Electron microscopy of the developing kidney : An investigation into the fine structure of the mesonephros and metanephros of the rabbit. Am. J. Anat., 94, 100-106.

MERCHANT H., 1975. Rat gonadal and ovarian organogenesis with and without germ cells : An ultrastructural study. Dev. Biol., 44, 1-21.

MERCHANT H., ZAMBONI L., 1972. Presence of connections between follicles in juvenile mouse ovaries. Am. J. Anat., 134, 127-132.

MOSSMAN H. W., DUKE K. L., 1973. Comparative morphology of the mammalian ovary. Univ. Wisconsin Press, Madison, Wisconsin.

PETERS H., PEDERSEN A., 1967. Origin of follicle cells in the infant mouse ovary. Fertil. Steril., 18, 309-313.

WALDEYER W., 1870. Eierstock und Ei. Englemann, Leipzig.

WILLIS R. A., 1958. The borderland of embryology and pothology. Butterworth and Co, London.

WILSON R. M., 1926. Correlation of external genitalia and sex glands in the human embryo. Contrib. Embryol. Carnegie Inst., 18, 23-30.

WINIWARTER, von H., 1900. Recherches sur l'ovogenèse ef l'organogenèse de l'ovaire des mammifères (lapin et homme). Arch. Biol., 17, 33-199.

WINIWARTER von H., SAINMONT G., 1908. Nouvelles recherches sur l'ovogenèse ef l'organogenèse de l'ovaire de mammifères (chat). Arch. Biol., 24, 373-431.

WITSCHI E., 1951. Embryogenesis of the adrenal and the reproductive glands. In PINCUS G., Recent Progr. Hormone Res., 6, 1-27, Acad. Press, New York.

WITSCHI E., 1956. Development of vertebrates. Saunders, Philadelphia.

WITSCHI E., 1962. Embryology of the ovary. In The ovary. Int. Acad. Pathol. Monogr., Vol. III, 1-10, Williams and Wilkins, Baltimore.

ZAMBONI L., BÉZARD J., MAULÉON P., 1979. The role of the mesonephros in the development of the sheep fetal ovary. Ann. Biol. anim. Biochem. Biophys., 19, 1153-1178.

ZAMBONI L., MERCHANT H., 1973. The fine morphology of mouse primordial germ cells in extragonadal locations. Am. J. Anat., 137, 299-335.

ZAMBONI L., STEFANINI M., 1968. On the configuration of the plasma-membrane of the mature spermatozoon. Fertil. Steril., 19, 570-579. 